\title{
Współdziałanie organów administracji publicznej a decyzje zależne na przykładzie unormowań dotyczących planu ruchu zakładu górniczego
}

\section{Wprowadzenie}

Złoża kopalin stanowią nieodnawialne, naturalne bogactwo narodowe. Ich pozyskiwanie powinno odbywać się w zgodzie z obowiązującymi w tym zakresie przepisami prawa.

Działalności polegającej na wydobywaniu kopalin nie należy wiązać jedynie z terenem Śląska i znajdującymi się tam kopalniami. Eksploatacja kopalin to działalność o szerokim zasięgu występowania. Dotyczy ona bowiem nie tylko wydobywania węgla, ale także piasków, żwirów czy kruszyw.

Podstawowym dokumentem, na którym opierają swoje działanie przedsiębiorcy zajmujący się eksploatacją kopalin, jest plan ruchu zakładu górniczego. Na przestrzeni dość długiego czasu był on wydawany w trybie współdziałania organów. Ze względu na to, że rozwiązanie przyjęte w art. 8 ust. 6 Ustawy z dnia 9 czerwca 2011 r. Prawo geologiczne i górnicze ${ }^{1}$, przewidujące potrzebę wcześniejszego uzyskania (wydania) innego rozstrzygnięcia w celu zatwierdzenia planu ruchu zakładu górniczego, różni się w odniesieniu do wskazanych niżej (pkt 2 niniejszego opracowania) założeń trybu współdziałania organów określonych w art. 106 Kodeksu postępowania administracyjnego ${ }^{2}$, można mieć wątpliwości, czy obecnie zalicza się ono do instytucji współdziałania organów.

\footnotetext{
${ }^{1}$ Tekst jedn. Dz.U. 2017, poz. 2126 ze zm., dalej "pr. geol.”.

${ }^{2}$ Ustawa z dnia 14 VI 1960 r. Kodeks postępowania administracyjnego (Dz.U. Nr 30, poz. 168 ze zm.), dalej „k.p.a.”.
} 
Prezentowane rozważania mają na celu udzielenie odpowiedzi na pytanie, czy ostatnie zmiany w Prawie geologicznym i górniczym pozwalają nadal wydawać plan ruchu zakładu górniczego w trybie współdziałania organów, czy też wprowadziły one odmienności polegające na tym, że obecnie mamy w tym przypadku do czynienia z decyzją zależna, tym bardziej że w literaturze przedmiotu wyraźnie podkreśla się, iż przepis art. 106 k.p.a. nie dotyczy decyzji zależnych, dla których decyzja poprzedzająca stanowi konieczny warunek ich wydania ${ }^{3}$.

\section{Współdziałanie organów - zagadnienia wstępne}

Współdziałanie organów administracji publicznej ma miejsce wówczas, gdy w jednej sprawie przecinają się zakresy działania dwóch lub więcej organów administracji publicznej, z których jednemu ustawodawca powierzył rolę wydania decyzji końcowo rozstrzygającej sprawę (organ rozpoznający sprawę i rozstrzygający postępowanie główne), a drugie$\mathrm{mu}$ (pozostałym) wyznaczył rolę pomocnicza, odzwierciedlającą się w poprzedzającym jej wydanie postanowieniu, wyrażającym stanowisko drugiego organu (organu współdziałającego)4.

Do najczęstszych przypadków wydawania decyzji administracyjnych w trybie współdziałania należą sytuacje, w których występuje tylko jeden organ współdziałający, tak jak np. w regulacji przewidzianej w art. 18 ust. 3a Ustawy z dnia 26 października 1982 r. o wychowaniu w trzeźwości i przeciwdziałaniu alkoholizmowi ${ }^{5}$, stanowiącej, że „zezwolenia [...] organ zezwalający wydaje po uzyskaniu pozytywnej opinii gminnej komisji rozwiązywania problemów alkoholowych zgodności lokalizacji punktu sprzedaży z uchwałami rady gminy". Można jednak wskazać i takie rozwiązania prawne, w których są dwa organy współdziałające (lub więcej). Przykładowo, zgodnie z art. 11 ust. 4 Ustawy z dnia 10 lipca

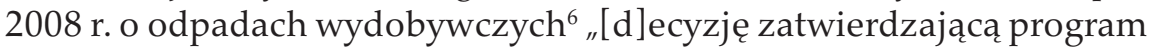
gospodarowania odpadami wydobywczymi wydaje się po zasięgnięciu opinii właściwego dyrektora okręgowego urzędu górniczego oraz właściwego wójta, burmistrza lub prezydenta miasta, a w przypadku,

${ }^{3}$ A. Wróbel, Art. 106, w: M. Jaśkowska, A. Wróbel, Kodeks postępowania administracyjnego. Komentarz, Warszawa 2000, s. 591.

${ }^{4}$ Por. S. Biernat, Działania wspólne administracji państwowej, Wrocław 1979, s. 38.

5 Tekst jedn. Dz.U. 2018, poz. 2137 ze zm.

${ }^{6}$ Tekst jedn. Dz.U. 2017, poz. 1849. 
o którym mowa w art. 27 ust. 9, również właściwego wojewódzkiego inspektora ochrony środowiska".

Współdziałanie organów administracji publicznej jest zarówno instytucją prawa procesowego, jak i materialnego. Jeśli jego zastosowanie zostanie przewidziane w przepisach prawa materialnego, skorzystanie z tego trybu ma charakter obligatoryjny. Obowiązek współdziałania pojawia się na ogół w sprawach, w których występuje wiele stron, samo zaś rozstrzygnięcie może nie tylko wpływać na prawa i obowiązki stron postępowania, ale także oddziaływać na prawa i obowiązki osób trzecich. Częstokroć ma on miejsce również wtedy, gdy realizacja decyzji może implikować skutki o istotnym znaczeniu społecznym ${ }^{7}$.

Tryb współdziałania organów został wprowadzony do ustawy z 1960 r. Kodeks postępowania administracyjnego w drodze jej nowelizacji w 1980 r. $^{8}$ Nie oznacza to jednak, że tryb współdziałania organów wcześniej, czyli przed 1980 r., nie był znany. Występował on już przed tą datą w polskim porządku prawa administracyjnego, gdyż podobnie jak obecnie, przewidywały go poszczególne rozwiązania normowane przepisami odrębnymi. Brakowało jednak unormowania, które regulowałoby ogólnie związane z tym trybem kwestie procesowe. Celem wprowadzenia - blisko czterdzieści lat temu - instytucji współdziałania do k.p.a. i ustalenia w ten sposób głównych założeń procesowych tego trybu było ujednolicenie założeń konstrukcji prawnej współdziałania organów ${ }^{9}$. Obecnie można jednak dostrzec liczne przykłady rozwiązań prawnych, w których ustawodawca poddał ten tryb wielu modyfikacjom.

W ramach instytucji współdziałania można wyróżnić organ decydujący oraz organ współdziałający. Pierwszy z nich, po uruchomieniu postępowania $\mathrm{w}$ danej sprawie, ma obowiązek zwrócić się do organu współdziałającego (bądź organów współdziałających) w celu wyrażenia opinii, zgody bądź zajęcia stanowiska w jeszcze innej formie, gdy jest to konieczne do prawidłowego rozpatrzenia i rozstrzygnięcia danej sprawy administracyjnej. Obowiązek współdziałania organów realizowany

${ }^{7}$ E. Szewczyk, Wybrane aspekty trybu wspótdziałania organów administracji publicznej, w: Aktualne problemy funkcjonowania samorzadu terytorialnego, pod red. E. Ury, E. Feret, S. Pieprznego, Sandomierz-Rzeszów 2017, s. 383-384.

${ }^{8}$ Ustawa z dnia 31 I 1980 r. o Naczelnym Sądzie Administracyjnym oraz o zmianie ustawy - Kodeks postępowania administracyjnego (Dz.U. Nr 4, poz. 8).

${ }^{9}$ J. Borkowski, Art. 106, w: B. Adamiak, J. Borkowski, Kodeks postępowania administracyjnego. Komentarz, Warszawa 2003, s. 435. 
jest z urzędu przez organ decydujący. Oznacza to, że nie jest on w stanie wydać prawidłowej decyzji administracyjnej bez udziału organu współdziałającego ${ }^{10}$. W przypadku decyzji ostatecznej jej wydanie bez uzyskania wymaganego wcześniej stanowiska innego organu może stanowić podstawę uruchomienia trybu wznowienia postępowania na podstawie art. $145 \S 1$ pkt 6 k.p.a.

Przepis art. 106 k.p.a. nie stanowi podstawy prawnej zastosowania trybu współdziałania organów. Stanowi ją przepis szczególny uzależniający wydanie decyzji od wyrażenia opinii (wyrażenia zgody bądź wyrażenia stanowiska w jeszcze innej formie) przez inny organ administracji publicznej. Obowiązek współdziałania często ma miejsce w sprawach z zakresu ochrony środowiska, zagospodarowania przestrzennego czy prawa budowlanego ${ }^{11}$.

Nakaz współdziałania organów w wyniku wprowadzenia do k.p.a. nowelizacją z 2017 r. - art. 7b ${ }^{12}$ został podniesiony do rangi zasady ogólnej w postaci zasady współdziałania organów administracji publicznej ${ }^{13}$. Zgodnie $z$ tym przepisem $w$ toku postępowania organy administracji publicznej współdziałają ze sobą w zakresie niezbędnym do dokładnego wyjaśnienia stanu faktycznego i prawnego sprawy, uwzględniając interes społeczny i słuszny interes obywateli oraz sprawność postępowania, za pomocą środków adekwatnych do charakteru, okoliczności oraz stopnia złożoności sprawy. Dzięki tej zasadzie oraz wprowadzonym przy okazji wspomnianej nowelizacji instrumentom, takim jak posiedzenie w trybie współdziałania (art. 106a k.p.a.), organ współdziałający oraz decydujący są jeszcze silniej niż dotychczas zdyscyplinowane i zaangażowane $\mathrm{w}$ rozwiązanie i rozstrzygnięcie danej sprawy $^{14}$.

${ }^{10}$ W. Sawczyn, Współdziałanie, w: Postępowanie administracyjne i sądowoadministracyjne z kazusami, pod red. R. Hausera, A. Skoczylasa, Warszawa 2017, s. 137.

${ }^{11}$ Por. wyrok Naczelnego Sądu Administracyjnego (NSA) z 26 VII 2017 r., sygn. I OSK 2824/16, LEX nr 2353941.

${ }^{12}$ Ustawa z dnia 7 IV 2017 r. o zmianie ustawy - Kodeks postępowania administracyjnego oraz niektórych innych ustaw (Dz.U. poz. 935).

${ }^{13}$ Zob. wyrok Wojewódzkiego Sądu Administracyjnego (WSA) w Poznaniu z 20 XII 2017 r., sygn. IV SA/Po 902/17, CBOSA.

${ }^{14}$ Zob. szerzej J. Człowiekowska, Zasada współdziałania organów administracji publicznej jako nowa zasada ogólna Kodeksu Postępowania Administracyjnego, s. 97 i n., Prawnicza i Ekonomiczna Biblioteka Cyfrowa Wydziału Prawa, Administracji i Ekonomii Uniwersytetu Wrocławskiego, http://repozytorium.uni.wroc.pl/dlibra/publication/95406/ edition/89608/content?ref=desc (dostęp: 2 II 2019). 


\section{Struktura trybu współdziałania organów}

Starając się uchwycić charakterystyczne cechy trybu współdziałania organów z punktu widzenia rozwiązania przyjętego w art. 106 k.p.a., można powiedzieć, że do istotnych czynności procesowych tego trybu należą wymienione niżej działania oraz następująca, wyznaczona przez ustawodawcę ich kolejność: (1) inicjatywa uruchomienia tego trybu leży po stronie organu administracji, którego zadaniem jest załatwienie sprawy w drodze rozstrzygnięcia jej decyzją administracyjną; (2) zwrócenie się do innego organu o zajęcie stanowiska w sprawie o czym należy powiadomić stronę - powinno mieć miejsce $\mathrm{w}$ trakcie postępowania głównego, a nie przed jego wszczęciem; (3) zwrócenie się o zajęcie stanowiska do innego organu uruchamia postępowanie wpadkowe (akcesoryjne), poddane regułom k.p.a.; (4) zajęcie stanowiska odbywa się w drodze postanowienia, podlegającego zaskarżeniu w drodze zażalenia, a następnie (ewentualnie) weryfikacji na drodze sądowoadministracyjnej; (5) w myśl nowego rozwiązania wprowadzonego do przepisu art. 106a k.p.a. zajęcie stanowiska może mieć miejsce w trybie wspólnego posiedzenia organów; (6) merytoryczne rozstrzygnięcie sprawy odbywa się $\mathrm{w}$ drodze wydania decyzji przez organ prowadzący postępowanie główne ${ }^{15}$. W kwestii terminu, w jakim powinno nastąpić zajęcie stanowiska, prawodawca kodeksowy ustalił ogólną regułę, w myśl której powinno to nastąpić niezwłocznie, nie później niż w terminie dwóch tygodni od doręczenia żądania, zastrzegając jednocześnie, że termin ten może być inaczej określony przez przepisy szczególne (art. 106 § 3 k.p.a.).

$\mathrm{W}$ wielu rozwiązaniach przyjętych $\mathrm{w}$ przepisach prawa instytucja współdziałania została ukształtowana w "czystej postaci”, dokładnie odpowiadającej wskazanym w wymienionych wyżej punktach czynnościom i ich sekwencji. Przykładem mogą być rozwiązania zawarte w art. 67 ust. 3 Ustawy z dnia 7 lipca 1994 r. - Prawo budowlane ${ }^{16}$, w myśl którego „[w] stosunku do obiektów budowlanych niewpisanych do rejestru zabytków, a objętych ochroną konserwatorską na podstawie miejscowego planu zagospodarowania przestrzennego, decyzję, o której mowa w ust. 1, organ nadzoru budowlanego wydaje po uzgodnieniu z wojewódzkim konserwatorem zabytków". Równie "czysta postać" s. 644 .

${ }^{15}$ R. Kędziora, Kodeks postępowania administracyjnego. Komentarz, Warszawa 2017,

${ }^{16}$ Tekst jedn. Dz.U. 2018, poz. 1202 ze zm. 
instytucji współdziałania występuje w jednym z rozwiązań przyjętych w Prawie geologicznym i górniczym. Zgodnie z art. 80 ust. 5 ab initio tej ustawy "[z]atwierdzenie projektu robót geologicznych wymaga opinii wójta (burmistrza, prezydenta miasta) właściwego ze względu na miejsce wykonywania robót"17.

\section{Charakter postępowania przed organem współdziałającym}

Powszechnie przyjmuje się, że postępowanie przed organem współdziałającym ma charakter pomocniczy, gdyż „organ współdziałający nie prowadzi odrębnej sprawy administracyjnej. Zajęcie przez niego stanowiska następuje $\mathrm{w}$ ramach już prowadzonego postępowania w sprawie głównej. Postępowanie przed organem współdziałającym ma [...] jedynie charakter pomocniczego stadium postępowania w sprawie rozstrzyganej $w$ drodze decyzji administracyjnej"18. Podobny pogląd wyraził NSA w orzeczeniu z 28 kwietnia 2003 r., kończąc swoją konstatację słowami: „ani przedmiot tego postępowania [prowadzonego przez organ współdziałający - E.Sz.], ani zapadające w nim rozstrzygnięcie nie mają samodzielnego bytu prawnego"19. Ze stanowiskiem tym koresponduje prezentowane w doktrynie stanowisko, że „organ współdziałający nie prowadzi odrębnej sprawy administracyjnej. Zajęcie przez niego stanowiska następuje $\mathrm{w}$ granicach już prowadzonego postępowania w sprawie głównej"20.

W tym kontekście podkreślenia wymaga, że w pewnym sensie postępowanie uzgodnieniowe (opiniujące) ma charakter odrębny. Wyraża się on w tym, że w każdym przypadku prowadzi je inny niż rozstrzygający w postępowaniu głównym organ administracji publicznej ${ }^{21}$, który pod względem ustrojowym i organizacyjnym w wykonywaniu swych

17 Por. wyrok WSA w Łodzi z 25 IV 2013 r., sygn. III SA/Łd 331/13, CBOSA.

${ }^{18}$ Wyrok NSA z 27 X 1998 r., sygn. II SA 1284/98, CBOSA.

${ }^{19}$ Wyrok NSA z 28 IV 2003 r., sygn. II SA 1817/01, LEX nr 157747; tak też NSA w wyroku z 13 X 2011, sygn. II OSK 1421/10, CBOSA.

${ }^{20}$ Ustawa o planowaniu i zagospodarowaniu przestrzennym, pod red. Z. Niewiadomskiego, Warszawa 2004, s. 432-433.

${ }^{21} \mathrm{~W}$ trybie współdziałania organem współdziałającym i organem załatwiającym sprawę nie może być jeden i ten sam organ, a tym samym tryb współdziałania nie dotyczy również stosunków między jednostkami organizacyjnymi urzędu powołanego do obsługi tego organu. Szerzej zob. G. Dobrowolski, Decyzja o środowiskowych uwarunkowaniach, Toruń 2011, s. 157; zob. też wyrok WSA w Łodzi z 14 III 2014 r., sygn. II SA/ Łd 1017/13, CBOSA. 
uprawnień jest organem posiadającym własne, jemu ustawowo przypisane kompetencje ${ }^{22}$. Można go uznać za "gospodarza” postępowania uzgodnieniowego (opiniującego). Prowadzi je więc odrębnie i w określonym stopniu niezależnie od postępowania prowadzonego w sprawie głównej. Owa niezależność polega np. na tym, że zapewniając stronom czynny w nim udział, powinien on samodzielnie dokonywać ustaleń w kwestii kręgu podmiotów posiadających w nim przymiot strony ${ }^{23}$, a także samodzielnie badać swoją właściwość do prowadzenia sprawy $\mathrm{W}$ ramach postępowania uzgodnieniowego (opiniującego) ${ }^{24}$.

Nie powinno jednak ulegać wątpliwości, że elementem łączącym obydwa postępowania jest przedmiot postępowania. Zarówno w sprawie głównej (rozstrzyganej decyzją), jak i w sprawie rozpoznawanej przez organ współdziałający (rozstrzyganej postanowieniem) przedmiot postępowania jest jeden i ten sam. Wyznacza go każdorazowo treść wniosku strony, występującej np. o udzielenie zezwolenia na sprzedaż napojów alkoholowych czy o ustalenie warunków zabudowy. W trybie współdziałania organów administracji publicznej widoczne są silne związki zachodzące między dwoma samodzielnymi organami, z których każdy powinien rozpatrywać leżącą w granicach jego kompetencji sprawę z innego punktu widzenia i na podstawie przepisów, których stosowanie wchodzi w zakres jego właściwości rzeczowej. Owe silne związki przejawiają się $\mathrm{w}$ tym, że dany organ nie może podjać rozstrzygnięcia w sprawie głównej bez uzyskania stanowiska organu współdziałającego, organ współdziałający nie mógłby zaś podjać działania bez wniosku organu prowadzącego postępowanie główne. Ponadto stanowisko organu współdziałającego w zależności od jego postaci może mieć słabszy bądź silniejszy wpływ na rozstrzygnięcie

${ }^{22}$ C. Martysz, Komentarz do art. 106 k.p.a., pkt 6, w: C. Martysz, A. Matan, G. Laszczyca, Kodeks postępowania administracyjnego. Komentarz, t. 2, LEX/el. 2010.

${ }^{23}$ Za trafny należy uznać pogląd wyrażony przez WSA w Krakowie w wyroku z 7 XI 2008 r., sygn. II SA/Kr 811/08, że organ uzgadniający może oprzeć się na wykazie stron przekazanym mu przez organ prowadzący postępowanie główne, jednakże nie jest nim związany i w sytuacji wpłynięcia pisma pochodzącego od osoby nieujętej w dotychczasowym wykazie jest on zobowiązany do zbadania, czy osoba taka jest stroną postępowania $\mathrm{w}$ rozumieniu art. 28 k.p.a. Nie jest bowiem wystarczającą podstawą do odmowy uznania tej osoby za stronę postępowania uzgodnieniowego fakt, że organ prowadzący postępowanie główne nie zaliczył jej do kręgu stron. Zob. też: wyrok WSA w Warszawie z 24 VI 2008 r., sygn. IV SA/Wa 639/08; wyrok NSA z 22 VI 2009 r., sygn. II OSK 1016/08; wyrok WSA w Warszawie z 10 IX 2008 r., sygn. IV SA/Wa 896/08 (CBOSA).

${ }^{24}$ E. Szewczyk, Wybrane aspekty trybu współdziałania..., s. 384-385. 
decyzji zapadającej w postępowaniu głównym, ale wpływ ten istnieje w każdym przypadku współdziałania ${ }^{25}$. Z tego względu w starszej literaturze przedmiotu oraz orzecznictwie sądów administracyjnych tryb obecnie najczęściej określany jako współdziałanie niekiedy jest nazywany mianem "współkompetencji” ${ }^{26}$.

\section{Rozwiązania prawne dotyczące planu ruchu zakładu górniczego}

Plan ruchu zakładu górniczego stanowi jedną z zasadniczych podstaw działania przedsiębiorców zajmujących się eksploatacją kopalin. Jest on sformalizowanym dokumentem zawierającym opis przedsięwzięć organizacyjno-technicznych oraz zadań produkcyjnych zapewniających prawidłową gospodarkę złożem oraz działań zabezpieczających przed negatywnym wpływem eksploatacji na środowisko ${ }^{27}$. Plan ruchu zakładu górniczego musi być zgodny z wymaganiami prawa geologicznego i górniczego oraz posiadaną przez przedsiębiorcę koncesją. Szczegółowe wymagania co do treści planu ruchu zakładu górniczego określa Rozporządzenie Ministra Ochrony Środowiska z dnia 8 grudnia 2017 r. w sprawie planów ruchu zakładów górniczych ${ }^{28}$.

Zgodnie z art. 108 ust. 6b pr. geol. plan ruchu zakładu górniczego, z wyłączeniem planu ruchu dla wykonywania robót geologicznych związanych z poszukiwaniem i rozpoznawaniem złoża węglowodorów, wymaga opinii właściwego wójta (burmistrza/prezydenta miasta). Kryterium opinii stanowi nienaruszenie zamierzoną działalnością przeznaczenia nieruchomości określonego w miejscowym planie zagospodarowania przestrzennego lub, w razie braku tego aktu, sposobu korzystania z nieruchomości określonego w studium uwarunkowań i studiów zagospodarowania przestrzennego gminy (art. 7 pr. geol.). W myśl art. 108 ust. 6c pr. geol. opinia jest wyrażana na wniosek przedsiębiorcy, w terminie 14 dni od dnia otrzymania wniosku. W przypadku niewyrażenia opinii w tym terminie uważa się, że właściwy wójt

${ }^{25}$ Ibidem, s. 385.

${ }^{26}$ J. Jendrośka, Komentarz do art. 106, w: J. Borkowski, J. Jendrośka, R. Orzechowski, A. Zieliński, Kodeks postępowania administracyjnego. Komentarz, Warszawa 1989, s. 202; zob. też postanowienie NSA z 24 V 1993 r., sygn. II SA116/93, CBOSA.

${ }^{27}$ Zob. wyrok NSA z 26 X 2016 r., sygn. II GSK 700/15, CBOSA.

${ }^{28}$ Dz.U. poz. 2293. 
(burmistrz/prezydent miasta) nie zgłasza uwag. Stosownie do art. 108 ust. 7 ab initio pr. geol. wniosek o zatwierdzenie planu ruchu zakładu górniczego przedkłada się organom właściwym dla miejsca prowadzenia robót objętych planem. Do wniosku o zatwierdzenie planu ruchu zakładu górniczego dołącza się opinię właściwego wójta (burmistrza/ prezydenta miasta) albo informację o jej braku, a w przypadku uwag także oświadczenie przedsiębiorcy o sposobie ich uwzględnienia lub przyczynach ich nieuwzględnienia (art. 108 ust. 9 pkt 3 pr. geol.). Jak stanowi art. 108 ust. 11 pr. geol., plan ruchu zakładu górniczego zatwierdza właściwy organ nadzoru w drodze decyzji.

W myśl przywołanych wyżej unormowań wniosek o zatwierdzenie w drodze decyzji administracyjnej planu ruchu zakładu górniczego przedkłada się zatem właściwemu organowi nadzoru górniczego, załączając do wniosku uzyskaną wcześniej przez przedsiębiorcę opinię właściwego wójta (burmistrza/prezydenta miasta) wyrażoną w drodze postanowienia.

W literaturze przedmiotu w świetle wcześniej obowiązującego stanu prawnego prezentowano stanowisko zaliczające konstrukcję wydawania przez wójta (burmistrza/prezydenta miasta) opinii w sprawie planu ruchu zakładu górniczego, powiązaną z wydawaniem decyzji o zatwierdzeniu planu ruchu zakładu górniczego, do instytucji trybu współdziałania organów ${ }^{29}$. Jak można domniemywać, stanowisko doktryny i judykatury w tym zakresie przez długi okres podyktowane było treścią uchwały składu pięciu sędziów Naczelnego Sądu Administracyjnego z 20 maja 1996 r. ${ }^{30}$, w której Sąd wskazał w dwóch punktach: po pierwsze, że "organem samorządu terytorialnego rzeczowo właściwym do wydania opinii, o jakiej mowa w art. 64 ust. 5 Ustawy z dnia 4 lutego 1994 r. - Prawo geologiczne i górnicze ${ }^{31}$, jest wójt lub burmistrz (prezydent miasta)"; po drugie, że "do wydania opinii, o której mowa wyżej, stosuje się przepis art. 106 k.p.a. z uwzględnieniem unormowań zawartych w art. 64 ust. 5 prawa geologicznego i górniczego". Uchwała ta została wydana na skutek wątpliwości powziętych przez Samorządowe Kolegium Odwoławcze co do tego, czy do wydania opinii stosuje się

${ }^{29}$ C. Martysz, Art. 106, pkt 9, w: C. Martysz, A. Matan, G. Laszczyca, Kodeks postępowania administracyjnego...; por. M. Szalewska, Art. 108, pkt 16, w: Prawo geologiczne i górnicze. Komentarz, pod red. B. Rakoczego, LEX/el. 2018.

${ }^{30}$ Uchwała Składu Pięciu Sędziów NSA z 20 V 1996 r., sygn. OPK 11/96, Legalis nr 40169.

${ }^{31}$ Dz.U. Nr 72, poz. 96. 
art. 106 k.p.a., które skłoniły ten organ do zadania pytania prawnego skierowanego do NSA.

Omawiana uchwała zapadła ponad dwadzieścia lat temu w nieobowiązującym obecnie stanie prawnym. W stanie prawnym obowiązującym od 1 stycznia 2015 r. nieco inaczej uregulowano omawiane kwestie. Zasadniczą różnicę stanowi to, że w myśl art. 64 ust. 5 poprzednio obowiązującej ustawy pr. geol., pod rządem której podjęto wskazaną wyżej uchwałę NSA, wydanie decyzji o zatwierdzeniu planu ruchu zakładu górniczego wymagało „uprzedniego przedłożenia przez przedsiębiorcę opinii". Ów stan prawny uległ zmianie już w 2011 r. poprzez wprowadzenie do art. 108 ust. 11 pr. geol. postanowienia, w myśl którego plan ruchu zakładu górniczego zatwierdza właściwy organ nadzoru górniczego, w drodze decyzji po uzyskaniu opinii właściwego wójta. Konstrukcja tego przepisu odpowiadała "czystej postaci” trybu współdziałania organów przyjętej w art. 106 k.p.a.

Po kolejnych czterech latach, z dniem 1 stycznia $2015 \mathrm{r}^{32}$, stan prawny ponownie uległ zmianie. Istotne novum stanowi to, że obecnie w myśl art. 108 ust. 9 pkt 3 pr. geol. opinię należy przedłożyć w momencie składania wniosku wszczynającego postępowanie, którego celem jest uzyskanie decyzji o zatwierdzeniu planu ruchu zakładu górniczego. Wskazany przepis wyraźnie bowiem traktuje tę opinię jako załącznik do podania wszczynającego postępowanie, stanowiąc: "do wniosku o zatwierdzenie planu ruchu zakładu górniczego dołącza się [...] opinię [...] albo informację o jej braku". W tym przypadku opinia ma postać załącznika do wniosku o wydanie decyzji. Oznacza to, że powinna ona funkcjonować w obrocie prawnym już w momencie składania owego wniosku wszczynającego postępowanie przed organem nadzoru górniczego, którego celem jest wydanie decyzji o zatwierdzeniu planu ruchu zakładu górniczego. Należy ją zatem uzyskać przed wszczęciem postępowania o wydanie decyzji zatwierdzającej plan ruchu zakładu górniczego. Ponadto nie można nie dostrzec, że inaczej niż w trybie współdziałania normowanym art. 106 k.p.a., inicjatywa związana z uzyskaniem opinii ewidentnie należy nie do organu wydającego decyzję ${ }^{33}$ o zatwierdzeniu planu ruchu zakładu górniczego, lecz do przedsiębiorcy, a więc wnioskodawcy. W tej sytuacji złożenie przez przedsiębiorcę wniosku dotkniętego brakiem polegającym na tym, że wnioskodawca

${ }^{32}$ Dz.U. 2014, poz. 1133.

${ }^{33}$ Zob. Z. Kmieciak, Zarys teorii postępowania administracyjnego, Warszawa 2014, s. 229. 
nie dołączył do niego opinii, o której mowa w art. 108 ust. 6b i 6c pr. geol., powinno spowodować skierowanie do niego wezwania o usunięcie braku w trybie art. 64 § 2 k.p.a.

Jedną z cech charakterystycznych konstrukcji trybu współdziałania organów jest to, że elementem łączącym obydwa postępowania: główne i wpadkowe (pomocnicze), jest przedmiot postępowania. Zarówno w sprawie głównej, jak i w sprawie rozpoznawanej przez organ współdziałający, przedmiot postępowania jest jeden i ten sam. Wyznacza go dokładnie treść wniosku strony występującej np. o udzielenie zezwolenia na sprzedaż napojów alkoholowych czy o ustalenie warunków zabudowy, bądź też o udzielenie koncesji na poszukiwanie, rozpoznawanie czy wydobywanie kopalin ${ }^{34}$. W trybie współdziałania organów administracji publicznej widoczne są silne związki zachodzące między dwoma samodzielnymi organami, z których każdy powinien rozpatrywać leżącą $w$ granicach jego kompetencji sprawę z innego punktu widzenia i na podstawie przepisów, których stosowanie wchodzi w zakres jego właściwości rzeczowej. Owe silne związki wyrażają się w tym, że organ nie może podjąć rozstrzygnięcia w sprawie głównej bez uzyskania stanowiska organu współdziałającego, organ współdziałający nie mógłby zaś podjacć działania bez wniosku organu prowadzącego postępowanie główne. Ponadto stanowisko organu współdziałającego w zależności od jego postaci może mieć słabszy bądź silniejszy wpływ na rozstrzygnięcie decyzji zapadającej w postępowaniu głównym, ale wpływ ten istnieje w każdym przypadku współdziałania. Z tego względu ugruntowany wydawał się pogląd prezentowany w literaturze przedmiotu oraz orzecznictwie sądów administracyjnych, w myśl którego tryb obecnie najczęściej określany jako współdziałanie określano mianem „współkompetencji”35. Obecnie w doktrynie prezentowane jest stanowisko, w myśl którego na gruncie prawa procesowego nie można mówić o współkompetencji przy wydaniu decyzji, gdyż jeden ze współdziałających organów nie uczestniczy w jej wydaniu, ale jedynie zajmuje stanowisko w formie postanowienia $^{36}$.

${ }^{34}$ E. Szewczyk, Wybrane aspekty trybu współdziałania..., s. 385.

${ }^{35}$ J. Jendrośka, Art. 106, w: J. Borkowski, J. Jendrośka, R. Orzechowski, A. Zieliński, Kodeks postępowania administracyjnego. Komentarz, Warszawa 1989, s. 202; zob. też postanowienie NSA z 24 V 1993 r., sygn. II SA116/93.

${ }^{36} \mathrm{H}$. Knysiak-Sudyka, Współkompetencja a współdziałanie organów w postępowaniu administracyjnym, w: Postępowanie administracyjne, pod red. T. Wosia, H. Knysiak-Sudyki, A. Golęby, M. Kamińskiego, T. Kiełkowskiego, Warszawa 2017, s. 184. 
Tymczasem przedmiot postępowania przed organem zatwierdzającym plan ruchu zakładu górniczego oraz przedmiot postępowania prowadzonego przed organem opiniującym nie pokrywają się. Jak wynika $\mathrm{z}$ art. 108 ust. $6 \mathrm{~b}$ pr. geol., zasadniczym kryterium, jakim powinien się kierować wójt (burmistrz/prezydent miasta) wydający opinię w sprawie, jest ocena tego, czy zamierzona działalność nie będzie naruszać przeznaczenia lub sposobu korzystania z nieruchomości (art. 7 pr. geol.). Oznacza to, że wójt (burmistrz/prezydent miasta) ocenia, czy planowana działalność zakładu górniczego nie naruszy przeznaczenia nieruchomości przewidzianego w miejscowym planie zagospodarowania przestrzennego, a w przypadku jego braku, czy nie naruszy ona sposobu korzystania z nieruchomości ustalonego w studium uwarunkowań i kierunków zagospodarowania przestrzennego gminy lub w odrębnych przepisach. Przykładowo, w przypadku braku planu miejscowego, jeżeli ze studium wynika, że teren działek, na których planowane jest prowadzenie zakładu górniczego, stanowi obszar gruntów rolnych, a ponadto $\mathrm{w}$ ich sąsiedztwie znajduje się zabudowa zagrodowa oraz droga gminna, wzdłuż której systematycznie rozwija się zabudowa zagrodowa oraz mieszkaniowa, prowadzenie zakładu górniczego na takim terenie byłoby niezgodne ze sposobem korzystania z gruntu określonym w studium.

Inny jest przedmiot postępowania prowadzonego przez organ nadzoru górniczego wydającego decyzję w przedmiocie zatwierdzenia planu ruchu zakładu górniczego niż postępowania prowadzonego przez wójta (burmistrza/prezydenta miasta) w celu wydania opinii. Plan ruchu zakładu górniczego w myśl art. 108 ust. 2 pr. geol. określa między innymi strukturę organizacyjną zakładu, zwłaszcza przez wskazanie osób z grona kierownictwa i dozoru ruchu, granice zakładu górniczego, szczegółowe przedsięwzięcia niezbędne w celu zapewnienia bezpieczeństwa powszechnego, bezpieczeństwa pożarowego, bezpieczeństwa osób przebywających w zakładzie górniczym, ochrony elementów środowiska. Ponadto stosownie do art. 108 ust. 3 pr. geol. plan ruchu zakładu górniczego sporządza się między innymi z uwzględnieniem warunków określonych w koncesji oraz odpowiednio w projekcie zagospodarowania złoża lub decyzji inwestycyjnej. Natomiast postanowienie wójta (burmistrza/prezydenta miasta) orzeka o zgodności zamierzenia polegającego na eksploatacji złoża kopaliny z planem miejscowym, a w razie jego braku - ze studium. Przedmiot postępowania prowadzonego przez wójta (burmistrza/prezydenta miasta) wydającego opinię, o której 
mowa w art. 108 ust. 6b i 6c pr. geol., jest zatem całkowicie odrębny od przedmiotu postępowania kończącego się decyzją o zatwierdzeniu długoterminowego aktu planowania określającego sposób i warunki działania zakładu górniczego.

Powyższe rozważania prowadzą do konkluzji, że opinia, o której mowa w art. 108 ust. 6b i 6c pr. geol., niezbędna dla wydania decyzji o zatwierdzeniu planu ruchu zakładu górniczego, nie powinna być wydawana przez wójta (burmistrza/prezydenta miasta) w trybie współdziałania organów, ale w całkowicie odrębnym postępowaniu poprzedzającym postępowanie kończące się wydaniem decyzji o zatwierdzeniu planu ruchu zakładu górniczego, z powodów, o których mowa dalej.

\section{Decyzja zależna}

Decyzja o zatwierdzeniu planu ruchu zakładu górniczego, o której mowa w art. 108 ust. 11 pr. geol., jest decyzją, którą należy traktować jako decyzję zależną (pochodną) względem rozstrzygnięcia wydawanego przez wójta (burmistrza/prezydenta miasta) w przedmiocie opinii, o której mowa w art. 108 ust. 6b i 6c pr. geol. Oznacza to, że jednym z prawnych warunków niezbędnych do wydania decyzji o zatwierdzeniu planu ruchu zakładu górniczego jest uprzednie wydanie opinii (która w myśl art. 108 ust. 6c może mieć także postać milczącą) przez wójta (burmistrza/prezydenta miasta) wyrażającej jego stanowisko co do tego, czy zamierzona działalność zakładu górniczego nie będzie naruszać przeznaczenia lub sposobu korzystania z nieruchomości określonych w miejscowym planie zagospodarowania przestrzennego, a $\mathrm{w}$ razie jego braku - $\mathrm{w}$ studium oraz $\mathrm{w}$ odrębnych przepisach. $\mathrm{W}$ takim przypadku organ nadzoru górniczego prowadzący postępowanie w przedmiocie wydania decyzji o zatwierdzeniu planu ruchu zakładu górniczego musi się oprzeć na innym rozstrzygnięciu, nazwanym przez ustawodawcę opinią wójta (burmistrza/prezydenta miasta), a wyrażoną w wyżej wskazanej sprawie. Decyzja organu nadzoru górniczego jest więc decyzją pochodna, gdyż organ nadzoru górniczego, podejmując własne rozstrzygnięcie, jest związany innym rozstrzygnięciem w postaci postanowienia organu jednostki samorządu terytorialnego. W dorobku judykatury, określając charakter decyzji zależnej, wskazuje się, że "[c]hodzi tu o rozstrzygnięcie jakiejś sprawy lub pojedynczej kwestii zawarte w decyzji administracyjnej lub w orzeczeniu sądowym wydanych 
w odrębnej i samodzielnej sprawie, stanowiące istotny fakt prawotwórczy w następnej, już innej sprawie administracyjnej w sytuacji, w której albo w ogóle nie mogłaby być wydana decyzja administracyjna, albo nie mogłaby być wydana decyzja administracyjna określonej treści bez stanu prawnego lub faktycznego ukształtowanego lub stwierdzonego wcześniejszym rozstrzygnięciem administracyjnym czy też sądowym innej - odrębnej sprawy. Zmiana bądź uchylenie decyzji administracyjnej lub orzeczenia sądowego powoduje, że od określonej daty albo upada istotny dla późniejszej sprawy fakt prawotwórczy, albo też zmienia się jego treść. W obu wypadkach jest podstawa do ponownego rozpatrzenia sprawy administracyjnej co do jej istoty" ${ }^{\prime \prime 7}$. Innymi słowy, związek między decyzją poprzedzającą a decyzją pochodną polega na tym, że decyzja poprzedzająca rozstrzyga o stanie prawnym determinującym rozstrzygnięcie decyzji zależnej (pochodnej) ${ }^{38}$.

W przypadku decyzji zależnych inna, poprzedzająca decyzja traktowana jest jako prejudykat rozstrzygnięcia innej sprawy. Uzyskanie decyzji zależnej jest zatem możliwe jedynie w razie wydania uprzednio innej decyzji administracyjnej, w odrębnym postępowaniu ${ }^{39}$. Przykładowo, decyzja środowiskowa stanowi podstawę wydania decyzji o pozwoleniu na budowę. Z kolei decyzja o pozwoleniu na budowę może stanowić podstawę decyzji o udzieleniu pozwolenia na użytkowanie. Podobna relacja występuje między decyzją o lokalizacji inwestycji celu publicznego bądź decyzją ustalającą warunki zabudowy a - w przypadku braku planu - decyzją o pozwoleniu na budowę; ponadto między decyzją o pozwoleniu na budowę a decyzją o wyłączeniu gruntów z produkcji rolnej ${ }^{40}$.

W rozważanym przypadku widoczny jest związek przyczynowy między wzmiankowanymi rozstrzygnięciami administracyjnymi przejawiający się w tym, że rozstrzygnięcie wcześniejsze (postanowienie zawierające opinię wójta, burmistrza czy prezydenta miasta) stanowi konieczną przesłankę prawną wydania decyzji późniejszej (decyzji o zatwierdzeniu planu ruchu zakładu górniczego) i jednocześnie stanowi

${ }^{37}$ Uchwała Składu Pięciu Sędziów NSA z 9 XI 1998 r., sygn. OPK 4-7/98.

${ }^{38}$ Zob. Z. Czarnik, Glosa do uchwaty NSA z 13 listopada 2012 r., I OPS 2/12, OSP 2013/5, poz. 55, s. 382-385.

${ }^{39}$ M. Wilbrandt-Gotowicz, Zintegrowane z prawem Unii Europejskiej postępowanie administracyjne, pkt 2.1.6, LEX/el. 2018.

${ }^{40}$ Więcej na temat zależności między decyzją o pozwoleniu na budowę a decyzją o wyłączeniu gruntów z produkcji rolnej zob. E. Szewczyk, Przejawy samowoli organów samorzadu terytorialnego, "Przedsiębiorczość i Zarządzanie” 2017, t. 18, z. 2, cz. 1, s. 180-181. 
jeden z warunków wydania nowej decyzji, a między nimi istnieje niewątpliwy bezpośredni i konieczny związek przyczynowy ${ }^{41}$.

Rozwiązanie przyjęte w przepisach pr. geol. w odniesieniu do zatwierdzenia planu ruchu zakładu górniczego nie stanowi przejawu trybu współdziałania organów uregulowanego od strony procesowej w art. 106 k.p.a. W tym przypadku bowiem inwestor we własnej osobie (a nie jak w przypadku współdziałania - organ podejmujący decyzję) zwraca się do innego organu w celu uzyskania opinii i czyni to jeszcze przed wszczęciem postępowania o zatwierdzenie planu ruchu zakładu górniczego. Ponadto - jak już wskazano - inny jest przedmiot obu tych postępowań.

W wyniku nowelizacji przepisów Prawa geologicznego i górniczego w 2015 r. ustawodawca wprowadził do jego postanowień ust. 6c $\mathrm{w}$ art. $108 \mathrm{w}$ celu przyspieszenia i uproszczenia procedury mającej na celu zatwierdzenie planu ruchu zakładu górniczego. W myśl tego rozwiązania opinia może być wyrażona w sposób milczący. Należy ją wyrazić w ciągu 14 dni od dnia złożenia wniosku. W przypadku niewyrażenia opinii w tym terminie uważa się, że właściwy organ (wójt, burmistrz, prezydent miasta) nie zgłasza uwag. W przypadku milczącego wyrażenia opinii przedsiębiorca powinien dołączyć do wniosku o wydanie decyzji w sprawie zatwierdzenia ruchu planu zakładu górniczego zaświadczenie o milczącym załatwieniu sprawy wydane na podstawie art. $122 \mathrm{f} \S 1$ k.p.a. Podkreślenia wymaga, że w świetle prezentowanych uwag nie znajdzie zastosowania do wydawania przedmiotowej opinii przepis art. 9 pr. geol. odnoszący się do instytucji współdziałania organów i przewidujący rozwiązanie zbliżone do unormowania z art. 108 ust. 6c. Stosownie do art. 9 ust. 2 pr. geol., jeżeli organ współdziałający nie zajmie stanowiska w terminie $14 \mathrm{dni}$, uważa się, że aprobuje przedłożony projekt rozstrzygnięcia. Na marginesie warto zauważyć, że istnienie tych dwóch podobnych, ale dotyczących innych przypadków norm (art. 9 i art. 108 ust. 6c pr. geol.) także przemawia za teza, że wydawanie opinii w przedmiocie planu ruchu zakładu górniczego nie odbywa się w trybie współdziałania organów. W przeciwnym bowiem przypadku w świetle założenia racjonalności prawodawcy przepis art. 108 ust. 6c pr. geol. należałoby uznać za zbędny.

${ }^{41}$ Por. W. Taras, Sądowa kontrola decyzji zależnych, w: Polski model sądownictwa administracyjnego, pod red. J. Stelmasiaka, J. Niczyporuka, S. Fundowicza, Lublin 2003, s. 345-346. 


\section{Podsumowanie}

Powyższe rozważania prowadzą do wniosku, że ustawodawca niekiedy zbyt "lekkomyślnie szafuje" instytucją współdziałania organów. Omawiany przykład jest tylko jednym z wielu. Pokazuje on, że ustawodawca bezrefleksyjnie przeszedł od niedostatecznie szczegółowego uregulowania, przyjętego w ustawie pr. geol. z 1994 r., którego charakter trzeba było wyjaśnić w trybie uchwały NSA udzielającej odpowiedzi na pytanie prawne, poprzez wprowadzenie trybu współdziałania w "czystej postaci" wyrażonego w regulacji ujętej w art. 108 ust. 11 pr. geol. w wersji ustalonej ustawą z 5 sierpnia 2011 r., w myśl której plan ruchu zakładu górniczego zatwierdzał właściwy organ zakładu górniczego, w drodze decyzji po uzyskaniu opinii właściwego wójta, aż do obecnie obowiązującego rozwiązania, którego nie można zaliczyć do trybu współdziałania organów. Co istotne bowiem, obydwa postępowania prowadzone przez organy wykonawcze gmin oraz przez organy administracji górniczej mają odrębne przedmioty postępowania. Opinia wójta (burmistrza/prezydenta miasta) wydawana jest w całkowicie osobnym postępowaniu, poprzedzającym postępowanie kończące się wydaniem decyzji o zatwierdzeniu planu ruchu zakładu górniczego. Bez znaczenia pozostaje to, że owa decyzja o zatwierdzeniu planu ruchu zakładu górniczego jest decyzją zależną nie od innej decyzji (co najczęściej ma miejsce np. w przypadku decyzji o pozwoleniu na budowę i decyzji o pozwoleniu na użytkowanie), lecz od rozstrzygnięcia wydawanego w postaci postanowienia, w tym od postanowienia, które może być wydane milcząco.

\section{CO-OPERATION OF PUBLIC ADMINISTRATION BODIES VS. DEPENDENT DECISIONS ON THE EXAMPLE OF REGULATIONS GOVERNING THE MINING PLANT OPERATION PLAN}

\section{Sum mary}

The aim of the article is to draw attention to the changes that have occurred in the regulations governing the mining plant operation plan, as a consequence of which such a document is no longer issued in the wording of 2018 on the mode of cooperation between the authorities regulated in Article 106 of the Act of 14 June 1960. - the Code of Administrative Procedure.

Mineral deposits are a non-renewable, natural national resource. They should be extracted in accordance with the provisions of the relevant generally applicable law. 
Their extraction cannot be regarded only in relation to the territory of Silesia and the mines located there. Exploitation of minerals is an activity with a very wide range of occurrence and concerns not only the extraction of coal, but also sands, gravels and aggregates.

When it comes to the provisions of the Act: Geological and Mining Law, there is much controversy as to whether this operation plan is being approved in the mode of the authorities co-operating with one another, or - in the light of current solutions - outside it. This paper explains the above controversies and shows that the decision on the approval of a mining plant operation plan is a dependent decision, proceeded however by a decision of a city mayor, or head of a village, issued in a completely separate proceeding, dealing with a different subject, not regulated in Article 106 of the Code of Administrative Procedure.

Keywords: administrative decision - dependent decision - cooperation mode mining plant operation plan 